Bull. Chem. Soc. Ethiop. 2020, 34(2), 215-226.

ISSN 1011-3924

(c) 2020 Chemical Society of Ethiopia and The Authors

Printed in Ethiopia

DOI: https://dx.doi.org/10.4314/bcse.v34i2.1

\title{
LEVELS OF SELENIUM IN SELECTED RIVER, WELL AND BOTTLED WATERS IN ETHIOPIA BY MICROWAVE PLASMA-ATOMIC EMISSION SPECTROMETRY
}

\author{
Ayenew Minuye, Feleke Zewge and Bhagwan Singh Chandravanshi* \\ Department of Chemistry, College of Natural and Computational Sciences, Addis Ababa \\ University, P.O. Box 1176, Addis Ababa, Ethiopia
}

(Received September 11, 2019; Revised August 31, 2020; Accepted September 7, 2020)

\begin{abstract}
Selenium is an essential trace element for many organisms, including humans, but it is toxic at higher level than homeostatic levels. Both selenium deficiency and toxicity are problems around the world (specially in China, India, USA). The level of selenium in selected waters of Ethiopia (including Akaki Kality river and some of its tributaries such as Kebena, Saris Abo, and Estifanos areas; bottled waters like Yes, Aqua Safe and Gift; well waters like Ziqualla Wogem, Akaki Kality and Ferensay Legasion; and tap water at Arat Kilo) were determined by microwave plasma-atomic emission spectroscopy after wet digestion and acidification. The levels selenium determined $(\mu \mathrm{g} / \mathrm{L})$ were $7.0,3.1,6.4,3.9,6.3,5.0,5.4,0.66,4.2,6.3$, and 2.0 , respectively. The percentage recovery of Se was found to be $95.2 \%$ which is in the acceptable range. The ANOVA result showed that there is a significant difference between the mean levels of selenium in the river, well and bottles waters. The results obtained in this study were compared with the permissible limit $(10 \mu \mathrm{g} / \mathrm{L})$ set by Ethiopian Standards Agency and the tolerable level set by WHO $(<40 \mu \mathrm{g} / \mathrm{L})$. Thus the levels of selenium detected in this study are within the recommended limit.
\end{abstract}

KEY WORDS: Selenium, Trace metal, Water samples, Microwave plasma-atomic emission spectroscopy, Ethiopia

\section{INTRODUCTION}

Selenium is a relatively rare trace element, ranking $68^{\text {th }}$ among the elements in the Earth's crust [1]. The average concentration of selenium in the igneous bedrock is only $0.05 \mathrm{mg} / \mathrm{kg}[2,3]$. The world's Se resource is limited because there are no ores from which selenium can be mined as a primary product $[2,3]$.

Selenium plays a key role in several major metabolic pathways such as thyroid hormone metabolism, antioxidant defense systems, and immune functions [4], has a supposed inhibitory effect in acquired immunodeficiency syndrome (AIDS) development and has beneficial roles in reproduction, cardiovascular diseases, and mood disorders [5-8]. Selenium may also play a detoxication effect due to the mutual antagonism with mercury and arsenic [9-12]. This protective role of selenium against mercury toxicity depends on the molar ratio between them but it is difficult and premature to establish a value [9]. However; depending mainly on its exposure dose, there is also a dark side of selenium. A high ( $400 \mu \mathrm{g}$ per day) intake of selenium causes pulmonary edema, abdominal pain, jaundice, chronic gastrointestinal diseases, hair loss and fatigue in humans and its deficiency result in Keshan disease, iodine deficiency disorders, and thyroid function, cancer, cardiovascular disease, and reproduction problem which are frequently reported in China [13].

The main source of selenium in the environment (e.g., hydrosphere, pedosphere, biosphere, and atmosphere) includes natural and anthropogenic sources. The natural source covers volcanic eruptions, sea spray, volatilization/recycling via biotic cycling, the weathering of seleniumcontaining rocks and soils, etc. [14]. Anthropogenic sources include mining, agriculture, coal combustion, semiconductors, pharmaceuticals, shampoos, oil refining, stainless-steel and glass manufacture industries [15].

*Corresponding author. E-mail: bscv2006@yahoo.com

This work is licensed under the Creative Commons Attribution 4.0 International License 
In the aquatic environment, selenium can rapidly attain levels that are toxic to fish and wildlife because of bioaccumulation in food chains and resultant dietary exposure. This rapid bioaccumulation causes the response curve for selenium poisoning to be very steep. For example, a transition from no effect to complete reproductive failure in fish can occur within a range of only a few $\mathrm{pg} / \mu \mathrm{L}$ (parts per billion) water borne selenium. Thus, activities that cause even slight increase in selenium level in water pose a major ecological risk and, much too often, leave natural resource managers trying to deal with selenium problems after they happen rather than anticipating and preventing them in the first place [16].

United States Environmental Protection Agency established selenium level at $5.0 \mu \mathrm{g} / \mathrm{L}$ as a chronic aquatic life criterion. This value was set in 1999 and is currently being updated [17]. World Health Organization (WHO) provisional guideline for Se in drinking water is set at 40 $\mu \mathrm{g} / \mathrm{L}$ [18]. European Union selenium limit in drinking water is $10 \mu \mathrm{g} / \mathrm{L}$ [19] and the maximum contamination level in the USA is $50 \mu \mathrm{g} / \mathrm{L}$ [17]. Australia and New Zealand have developed a joint guideline for fresh and marine water quality with a triggered value of $11 \mu \mathrm{g} / \mathrm{L}$ (total selenium) for the protection of $95 \%$ of freshwater species [20]. South Africa established a chronic effect value of $5 \mu \mathrm{g} / \mathrm{L}$ for the toxic effects of selenium on aquatic organisms [21]. India's standard for the maximum selenium concentration in all industrial effluents to surface waters, marine and coastal areas, and to public sewers is $50 \mu \mathrm{g} / \mathrm{L}$ [22]. In Canada, most provincial and territorial guidelines on selenium refer to the Canadian Environmental Quality Guidelines (CEQGs), which recommend $1 \mu \mathrm{g} / \mathrm{L}$ for freshwater, $20 \mu \mathrm{g} / \mathrm{L}$ for continuous irrigation, $50 \mu \mathrm{g} / \mathrm{L}$ for intermittent irrigation, and $50 \mu \mathrm{g} / \mathrm{L}$ for livestock feed water [23]. The updated guidelines provide fresh and marine water quality guidelines $(2 \mu \mathrm{g} / \mathrm{L})$, whole-body fish tissue guidelines $(4 \mu \mathrm{g} / \mathrm{g}$, dry weight), fish egg/ovary guidelines $(11 \mu \mathrm{g} / \mathrm{g}$, DW), and muscle tissue guidelines (4 $\mu \mathrm{g} / \mathrm{g}$, dry weight) [24]. Ethiopian Standards Agency has set permissible level of selenium in drinking water as $10 \mu \mathrm{g} / \mathrm{L}$ [25].

World average selenium concentration in freshwater is $0.02 \mu \mathrm{g} / \mathrm{L}[26]$ and in seawater below $0.08 \mu \mathrm{g} / \mathrm{L}$ [27]. Groundwater generally contains higher selenium levels than surface waters, due to the contact with rocks. Oceans, via seafood, and drinking-water play an important role in human selenium exposure. The wastewater resulting from FGD (flue-gas-desulfurization) contains selenium, in a typical concentration of $1-10 \mathrm{mg} / \mathrm{L}$ [28]. In mining wastewaters, selenium can be found in concentrations ranging from $3 \mu \mathrm{g} / \mathrm{L}$ to above $12 \mathrm{mg} / \mathrm{L} \mathrm{[29].}$

The unique and complex behavior of Se in the aquatic environment is further reflected by inconsistent environmental guidelines around the world. It is widely accepted that the concentration of $\mathrm{Se}$ in fish tissue is a more reliable the measure of Se exposure and potential ecological effects than the concentration of Se in water; however concentration thresholds have also been the focus of considerable research and debate [30-32]. In 2016, the United States Environmental Protection Agency (US EPA) issued a new aquatic guideline for Se that prioritizes a fish tissue-based criterion (muscle or gonads) over water-based criteria [33]. If data for fish tissue is not available then guideline values for dissolved Se concentrations in water take precedence, and differ for lotic $(3.1 \mu \mathrm{g} / \mathrm{L})$ and lentic systems $(1.5 \mu \mathrm{g} / \mathrm{L})[33]$.

A particularity of selenium is that the boundary between toxicity and deficiency is narrow [34] and still not cleared. The toxicity of selenium is not only related to its chemical similarity to sulfur and to its ability to be substituted during the assembly of proteins, but also to the oxidative stress [35]. Selenium species, particularly the inorganic ones, react with thiols and generate oxygen free radicals that account to Se toxicity to cells [36, 37].

Water, food and air in decreasing order are identified earlier as source of human toxicity from selenium. Moreover, drinking water sources remains to be a concern in geogenic selenium contamination [3]. It is present in trace amounts in both organic and inorganic forms in marine and freshwater systems, soils, biomasses and in the atmosphere. Human dietary Se intake is largely governed by Se concentrations in plants. The mobilization of Se across soil-plant-atmosphere interfaces is thus of crucial importance for human Se status 
[26]. Consumption of Se based food (cereals, vegetables, legumes and pulses) is the prime source of Se exposure to human [2].

Precise knowledge of the amounts of selenium and its compounds present in a system are therefore required for accurate assessment of the environmental and biological impact of selenium. There is one study done on the levels of selenium in drinking water samples from the Ethiopian Rift Valley from deep wells, shallow wells, hot springs, springs and rivers [38] and reported Se level within the WHO permissible limit. In another study level of selenium in water samples from Tinishu Akaki River, Lake Awassa, and Lake Ziway, Ethiopia was reported within the WHO permissible limit [39]. The levels of selenium have also been determined in the Swiss chard and sediment of the Akaki River, Ethiopia [40] and sediment of Lake Awassa and Lake Ziway, Ethiopia [41]. Merga et al. [42] have reviewed the spatiotemporal variation of water quality of Lake Ziway based on nutrients and metals including selenium. However, there is no any report on the level of selenium in the water of Akaki Kality River and some of its tributaries, well water from Ferensay Legasion, Akaki Kality, Ziqualla Wogem area, selected bottled water and tap water, which are commonly used for drinking in Ethiopia. Therefore, it is worthwhile to determine selenium in selected water samples of Ethiopia by microwave plasmaatomic emission spectroscopy.

The main objective of this study was to determine the concentration of selenium in selected river, well, and bottled waters in Ethiopia. The specific objectives of the study were: (i) to compare selenium level among well, surface and bottled waters in Ethiopia and (ii) to compare the results of this research with selenium limit set by different countries and international guidelines.

\section{EXPERIMENTAL}

\section{Chemicals and reagents}

All the reagents used in this study were of analytical grade. Sodium selenite pentahydrate, $\mathrm{Na}_{2} \mathrm{SeO}_{3} .5 \mathrm{H}_{2} \mathrm{O}$ (Vapi, Gujarat, India) was used to prepare the stock standard solution of selenium. $69 \% \mathrm{HNO}_{3}$ and $37 \% \mathrm{HCl}$ (both from Himedia Laboratories Pvt. Ltd, India) were used throughout the study. Deionized water was used throughout the study.

\section{Equipment}

A digital analytical balance, manufactured by Adam equipment (USA) with a precision of $\pm 0.0001 \mathrm{~g}$ was used weigh $\mathrm{Na}_{2} \mathrm{SeO}_{3} .5 \mathrm{H}_{2} \mathrm{O}$ to prepare a standard solution. Micropipette was used to measure the volume of the stock standard solution for the preparation of working standard solution. A Kjeldhal digestion block (Gallenkamp, UK) was used for digestion of water samples, blank solutions, and spiked samples. A refrigerator was used to store the digested samples until analysis. Microwave plasma-atomic emission spectrometer (Agilent $4200 \mathrm{MP}-$ AES, USA) with microwave-induced nitrogen plasma as an excitation source and optical dispersion and detection at a selected wavelength were used for the determination of Se in water samples. All measurements were performed using an Agilent 4200 MP-AES with nitrogen supplied from an Agilent 4107 Nitrogen Generator. The sample introduction system consisted of a micro mist nebulizer, double pass glass cyclonic spray chamber and solvent resistant sample tubing. An External Gas Control Module (EGCM) accessory was used to inject a flow of air into the plasma to prevent carbon deposits from building up in the torch, overcome any plasma instability that may arise from the analysis of organic samples, and to reduce background emissions caused by carbon species in the plasma. The instrument is controlled by the intuitive MP Expert software. The MP-AES features continuous wavelength coverage and MP Expert software automatically adds the recommended wavelength, nebulizer flow rate, and EGCM setting when elements are selected for simplified method development. 
Sample collection

In the present study four types of water samples including well, bottled, river, and tap waters from eleven sources were collected randomly for the analysis by polyethylene plastic containers. Six representative well water samples from Ziqulla Wogem Kebele in Dega Damot Woreda having about 10 meter depth were collected and mixed together for the analysis. Most of the people in the area are using well water for drinking and irrigation purposes. Bottled waters were purchased from the locally available market of Addis Ababa. The reason of sampling bottled water was due to continuous increase in consumption of bottled water in urban areas. Therefore, Se level of bottled water was the interest of the study. River water samples were collected from Akaki Kality River and some of its tributaries such as Kebena, Saris Abo, Estifanos at the bridged areas at a depth of $50 \mathrm{~cm}$. The reason of sampling was to assess the anthropogenic source of Se in the area. Tap water samples were taken from Arat Kilo area that comes from Legedadi dam. It is the most important single purpose reservoir, provides about $80 \%$ of the household water supply to Addis Ababa City and its Main Distribution Line (LL1-LL4) encompasses Arat Kilo area. Well water of Akaki Kality water reservoir was taken to compare the level of Se with different well water of Ethiopia. Currently well water is the possible source of water supply for both urban and rural communities in Ethiopia.

\section{Sample preparation}

Polyethylene plastic containers were used for collecting the water samples. All the samples were acidified with $2 \%$ nitric acid to reduce $\mathrm{pH}<2$ in order to minimize precipitation, adsorption to container wall and microbial degradation. After $24 \mathrm{~h}, 100 \mathrm{~mL}$ acidified well water and Akaki Kality and its tributary river water samples were transferred to a $500 \mathrm{~mL}$ borosilicate beaker for digestion as described by US EPA [43]. In the digestion process, $2 \mathrm{~mL} \mathrm{HNO}_{3}(69 \%)$ and $5 \mathrm{~mL}$ $\mathrm{HCl}(37 \%)$ were used and digestion was performed until sample volume reduced to $20-25 \mathrm{~mL}$. The beaker was removed from the hot plate and allowed to cool to room temperature. The sample was filtered with Whatman filter paper to remove silicates and other insoluble material and the filtrate was collected in a cleaned and pre-rinsed filtering flask with dilute $\mathrm{HNO}_{3}$. The beaker and watch glass were washed with water and the washings were added to the filtered sample. The sample was diluted to $100 \mathrm{~mL}$ with deionized water and used for the analysis by MP-AES. Tap water and bottled water samples were directly analyzed without digestion because these waters are clear and directly consumed by human and hence expected to be free from contaminant [44]. Thus $25 \mathrm{~mL}$ acidified tap and bottled water samples were taken. Finally, about $75 \mathrm{~mL}$ deionized water was added to dilute the sample to $100 \mathrm{~mL}$. The diluted samples were kept in a refrigerator until analysis by MP-AES.

\section{Standard solution of selenium}

A $40 \mu \mathrm{g} / \mathrm{L}$ Se stock solution was prepared dissolving known weight of $\mathrm{Na}_{2} \mathrm{Se}_{2} \mathrm{O}_{3} .5 \mathrm{H}_{2} \mathrm{O}$ in deionized water. Working standard solutions $(5,10,15$ and $20 \mu \mathrm{g} / \mathrm{L})$ were prepared from serial dilution of stock solution with de-ionized water.

\section{Calibration curve}

Emission intensities of working standard solutions (5, 10, 15 and $20 \mu \mathrm{g} / \mathrm{L})$ were measured and calibration curve was constructed. The correlation coefficient of the calibration curve $(y=$ 100.78x-7.6) was 0.9996. The calibration curve is shown in Figure 1. 


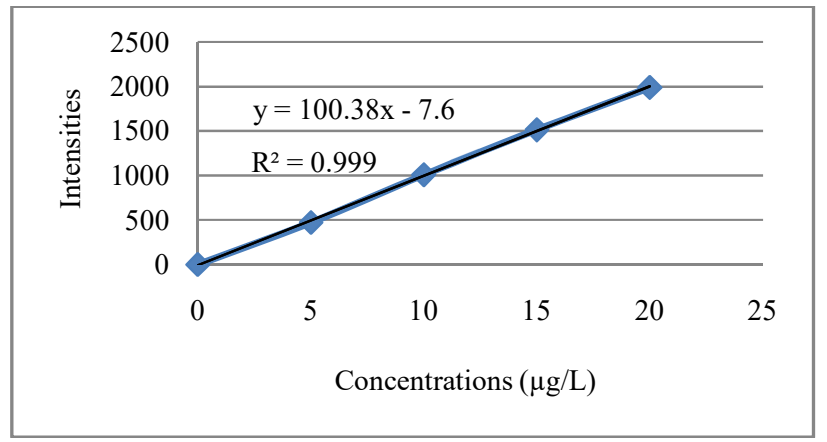

Figure 1. Calibration curve for Se determination.

\section{Method detection limit}

The method detection limit is the amount of analyte that gives signal equal to three times the standard deviation of the blank. In this study after the digestion of three blank solutions containing $\mathrm{HNO}_{3}(69 \%)$ and $\mathrm{HCl}(37 \%)$ three readings were taken from MP-AES and the standard deviation were calculated. $\mathrm{MDL}=3 \times \mathrm{SD}$ of blank, where SD is the standard deviation of the blank. The method detection limit (MDL) was calculated as three times the standard deviation of the blank and found to be $0.2 \mu \mathrm{g} / \mathrm{L}$ which clearly indicated that selenium can be detected in the water samples at trace level.

Recovery test

A $100 \mathrm{~mL}$ Akaki Kality River water sample $(7.0 \mu \mathrm{g} / \mathrm{L} \mathrm{Se})$ was spiked with $1.4 \mu \mathrm{g} / \mathrm{L}$ Se. The spiked sample was digested and its Se content was determined. The result was expressed as \% recovery. The recovery test results are summarized in Table 1 . The recovery result for Se was $95.2 \%$ which is within the acceptable range. Thus, good recovery was obtained for the analyte in Akaki Kality river water.

Table 1. Recovery test results for Se in Akaki Kality River water sample.

\begin{tabular}{|c|c|c|c|c|c|c|c|}
\hline Trials & $\begin{array}{c}\text { Conc. in } \\
\text { unsipked } \\
\text { sample }(\mu \mathrm{g} / \mathrm{L})\end{array}$ & $\begin{array}{l}\text { Mean conc. in } \\
\text { unspiked } \\
\text { sample }(\mu \mathrm{g} / \mathrm{L})\end{array}$ & $\begin{array}{l}\text { Amount } \\
\text { added } \\
(\mu \mathrm{g} / \mathrm{L})\end{array}$ & $\begin{array}{c}\text { Conc. in spiked } \\
\text { sample) } \\
(\mu \mathrm{g} / \mathrm{L})\end{array}$ & $\begin{array}{l}\text { Mean conc. in } \\
\text { spiked sample } \\
(\mu \mathrm{g} / \mathrm{L})\end{array}$ & $\begin{array}{c}\text { Recovery } \\
(\%)\end{array}$ & $\begin{array}{c}\text { Mean recovery } \\
(\%)\end{array}$ \\
\hline 1 & 6.6 & \multirow{3}{*}{ 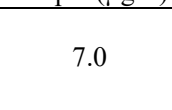 } & \multirow{3}{*}{1.4} & 7.9 & \multirow{3}{*}{$\left.(\mu)^{\prime}-1\right)$} & 92.9 & \multirow{3}{*}{95.2} \\
\hline 2 & 7.0 & & & 8.3 & & 92.9 & \\
\hline 3 & 7.4 & & & 8.8 & & 100 & \\
\hline
\end{tabular}

Statistical analysis

Microsoft Excel was used for the data treatment and for the analysis of variance (ANOVA) to indicate the presence or absence of significant differences in the mean concentration of Se in the samples.

\section{RESULTS AND DISCUSION}

Level of selenium in different water samples

The level of selenium determined in the well, bottled, river and tap water samples is given in Table 2. 
Table 2. Level of selenium in different water samples.

\begin{tabular}{|c|c|c|c|}
\hline Types of sample & $\begin{array}{c}\text { Level of Se } \\
\text { mean }(\mu \mathrm{g} / \mathrm{L})\end{array}$ & $\begin{array}{c}\mathrm{SD}(\mathrm{n}=3) \\
(\mu \mathrm{g} / \mathrm{L})\end{array}$ & $\%$ RSD \\
\hline \multicolumn{4}{|l|}{ River water } \\
\hline Akaki Kality River & 7.0 & 0.36 & 5.2 \\
\hline Saris Abo area river & 6.4 & 0.21 & 3.3 \\
\hline Estifanos area river & 3.9 & 0.33 & 8.4 \\
\hline Kebena area river & 3.1 & 0.18 & 5.7 \\
\hline \multicolumn{4}{|l|}{ Well water } \\
\hline Well water at Ferensay Legasion & 6.3 & 0.07 & 1.1 \\
\hline Well water at Akaki Kality & 4.2 & 0.27 & 6.4 \\
\hline Well water of Ziqualla Wogem & 0.66 & 0.06 & 9.1 \\
\hline \multicolumn{4}{|l|}{ Bottled water } \\
\hline Yes bottled water & 6.3 & 0.48 & 7.6 \\
\hline Gift bottled water & 5.4 & 0.09 & 1.7 \\
\hline Aqua Safe bottled water & 5.0 & 0.34 & 6.8 \\
\hline \multicolumn{4}{|l|}{ Tap water } \\
\hline Tap water at Arat Kilo & 2.0 & 0.10 & 5.0 \\
\hline
\end{tabular}

It can be seen from Table 2 that Akaki Kality River water sample contains the highest level of selenium where as well water collected from Ziqulla Wogem contain the lowest level of selenium among the water samples analyzed in the present study. Thus, the anthropogenic activities (industrial waste water and chemicals and fertilizers used in agricultural activities) in Addis Ababa city are the possible causes for the higher level of selenium in Akaki Kality River water while the natural existence of selenium in Ziqulla Wogem well water is at the lowest level. Since the only source of Se in the well water is from the dissolution of rock, the lowest level of Se in well water of Ziqulla Wogem may be due to the existence of parent rock that have relatively poor source of Se.

The level of selenium in the waters of Akaki Kality River and its tributaries namely, Saris Abo, Estifanos, and Kebena areas are 7.0, 6.4, 3.9 and $3.1 \mu \mathrm{g} / \mathrm{L}$, respectively (Figure 2). From the results, it is possible to infer that the level of selenium in Akaka Kality River water is higher than its tributaries. The data indicated that the contamination level of rivers increases from top to bottom of tributary rivers that joined the Akaka Kality River. Therefore, vegetables irrigated with Akaka Kality river water will grow with higher level of selenium than its tributaries.

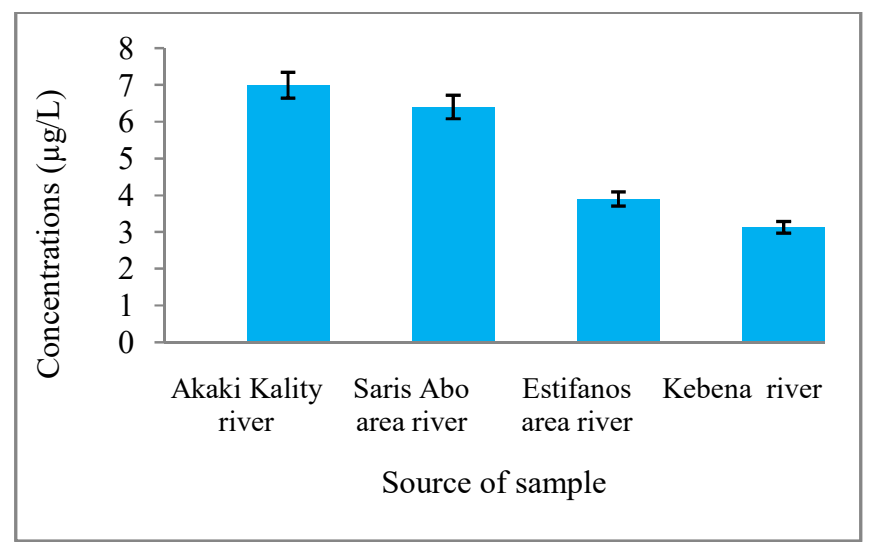

Figure 2. Level of selenium in waters of Akaki Kality River (main river) and its tributaries.

Bull. Chem. Soc. Ethiop. 2020, 34(2) 
The level of selenium in Yes, Gift and Aqua Safe bottled water samples are 6.3, 5.4 and 5.0 $\mu \mathrm{g} / \mathrm{L}$, respectively (Figure 3). Yes bottled water has the highest selenium content whereas Aqua Safe bottled water has the lowest selenium content. Therefore the parent rock at Wechecha Mountain, located in Sebeta, Oromia Region is good source of dissolved selenium. The rock found in Debre Birhan, Amhara and Sululta, Oromia region have almost comparable dissolved selenium content.

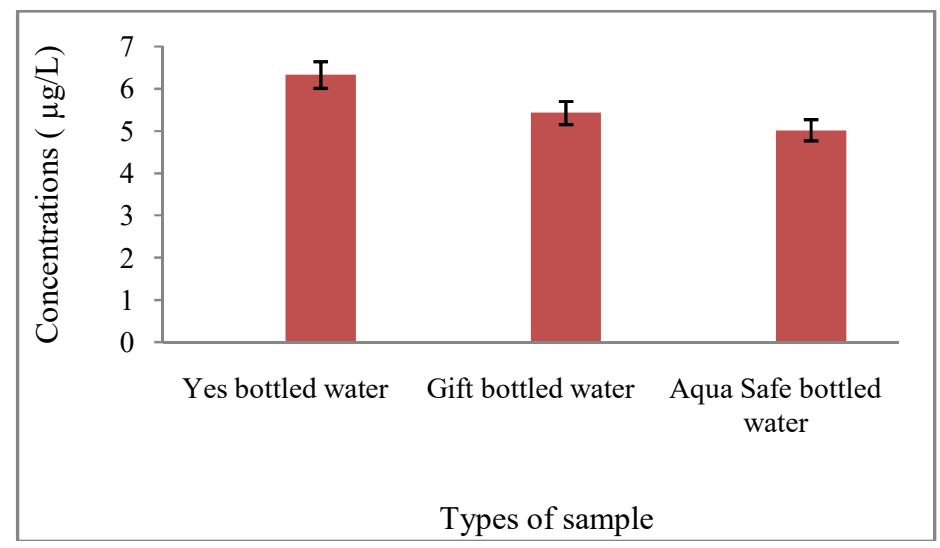

Figure 3. Level of selenium in different bottled waters.

The amount of selenium in well water of Ziqualla Wogem, Akaki Kality, and Ferensay Legasion are $0.66,4.2$ and $6.3 \mu \mathrm{g} / \mathrm{L}$, respectively (Figure 4). The level of selenium is different in different areas of well water. Therefore, the rocks in Ferensay Legasion are good source of dissolved selenium than Ziqualla Wogem. Even the amount of selenium in well water of Ferensay Legasion, $6.3 \mu \mathrm{g} / \mathrm{L}$ is in comparable amount with that of Saris Abo Area River, 6.4 $\mu \mathrm{g} / \mathrm{L}$, which is expected to be polluted with anthropogenic sources. This result indicates that the weathering of rocks have a significant effect on concentration of dissolved selenium content.

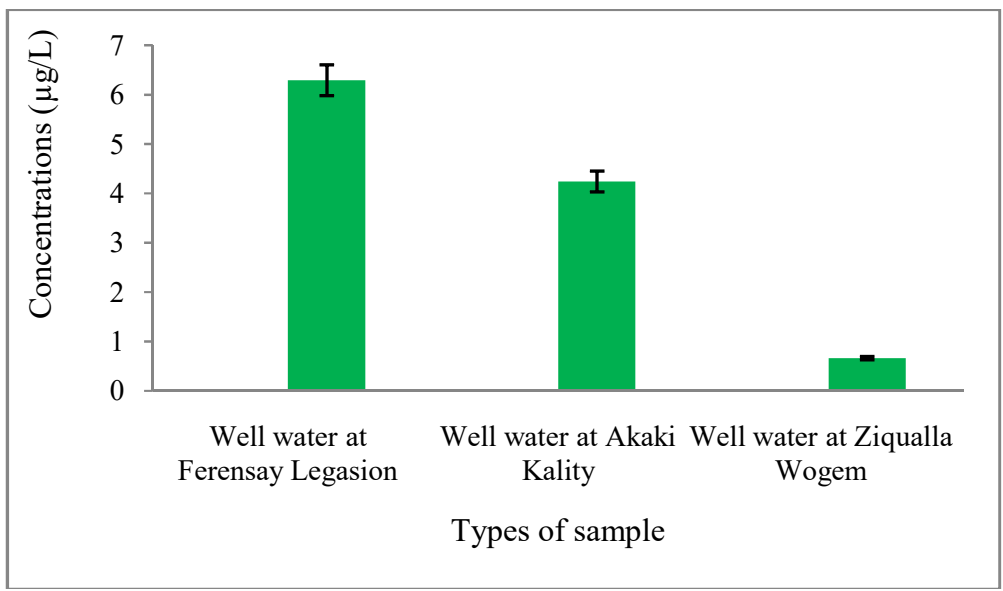

Figure 4. Levels of selenium in different well water. 
Statistical analysis of variance (ANOVA)

In analytical work, ANOVA is used to identify the source of variation of the means of different experiments. Thus, in this study, it was used to check whether there is a significant difference or not between samples mean at $\mathrm{p}=0.05$. The mean levels of selenium do not differ significantly between Akaki Kality River water and Saris Abo area river water. There is also no significant difference in the mean level of Se between Estifanos area river water and Kebena area river water. But the levels of Se in the water of Akaki Kality River and Saris Abo area river are significantly different from the levels of Se in the water of Estifanos area river and Kebena area river. There is no significant difference in the level of Se in the three bands of bottled water (Yes, Gift and Aqua Safe). In contrast to the bottled water, the levels of Se in the three well waters from Ferensay Legasion, Ziqualla Wogem and Akaki Kality differ significantly from each other. The level of Se in the tap water differs significantly from the three types of water from all the ten sources.

Comparison of selenium levels in water bodies in Ethiopia with the provisional guideline of selenium in different countries

The unique and complex behavior of Se in the aquatic environment is reflected by inconsistent environmental guidelines around the world [45]. Table 3 shows the concentration of selenium set by different agencies and countries. Comparison of the Se levels found in the different types of water of Ethiopia with the WHO guideline for freshwater indicates that the Se levels in the fresh waters of Ethiopia well below the WHO limit [18] and the limit set by Ethiopian Standards Agency [25]. There is no any guideline in Ethiopia. The Se levels in the different types of water of Ethiopia are either below or comparable with the guidelines of most countries.

Table 3. Provisional guidelines of selenium set by different agencies and countries.

\begin{tabular}{|l|l|l|}
\hline Countries/agencies & $\begin{array}{l}\text { The maximum } \\
\text { concentration of Se in } \\
\text { provisional guidelines }\end{array}$ & Existences \\
\hline Ethiopia (this study) & $0.66-7.0$ & $\begin{array}{l}\text { Tap water, bottled water, well water, } \\
\text { river water }\end{array}$ \\
\hline Ethiopian Standards Agency [25] & $10 \mu \mathrm{g} / \mathrm{L}$ & Drinking water \\
\hline US EPA [17, 33] & $5.2 \mathrm{mg} / \mathrm{kg}$ & Fish eggs or ovaries \\
\cline { 2 - 3 } & $1.8 \mathrm{mg} / \mathrm{kg}$ & Fish muscle \\
\cline { 2 - 3 } & $1.3 \mu \mathrm{g} / \mathrm{L}$ & Lentic aquatic systems \\
\cline { 2 - 3 } & $4.8 \mu \mathrm{g} / \mathrm{L}$ & Lotic aquatic systems \\
\hline Australia and New Zealand [20] & $11 \mu \mathrm{g} / \mathrm{L}$ & Species for fresh and marine water \\
\hline South Africa [21] & $5 \mu \mathrm{g} / \mathrm{L}$ & Aquatic organisms \\
\hline India [22] & $50 \mu \mathrm{g} / \mathrm{L}$ & Industrial effluents to surface waters \\
\hline Canada [23, 24] & $1 \mu \mathrm{g} / \mathrm{L}$ & Freshwater \\
\cline { 2 - 3 } & $20 \mu \mathrm{g} / \mathrm{L}$ & For continuous irrigation \\
\cline { 2 - 3 } & $50 \mu \mathrm{g} / \mathrm{L}$ & For intermittent irrigation \\
\cline { 2 - 3 } & $50 \mu \mathrm{g} / \mathrm{L}$ & For livestock feed water \\
\hline Britain [19] & $2 \mu \mathrm{g} / \mathrm{L}$ & $\begin{array}{l}\text { Fresh and marine water } \\
\text { guidelines }\end{array}$ \\
\hline & $4 \mu \mathrm{g} / \mathrm{g}$ & Whole-body fish tissue guidelines \\
\cline { 2 - 3 } & $11 \mu \mathrm{g} / \mathrm{g}$ & Fish egg/ovary and muscle tissue \\
\hline WHO [18] & $40 \mu \mathrm{g} / \mathrm{L}$ & Freshwater \\
\hline
\end{tabular}




\section{Comparison of selenium levels in different countries reported in literature}

There are several reports on the levels of selenium in different types of samples in different countries. Comparison of the Se levels found in the different types of water of Ethiopia with the levels of Se reported in the literature is summarized in Table 4. The Se levels in the different types of water of Ethiopia are either below or comparable with the reported levels of $\mathrm{Se}$ in different types of samples from different countries.

Table 4. Concentration of selenium in the environment of the countries/areas affected by excessive selenium.

\begin{tabular}{|l|l|l|l|}
\hline Countries & Types of sample & Concentrations & Reference \\
\hline Amman Zarqa Basin, Jordan & Lower aquifer & $1.6-30 \mu \mathrm{g} / \mathrm{L}$ & {$[46]$} \\
\hline Amman Zarqa Basin, Jordan & Upper aquifer & $0.4-246 \mu \mathrm{g} / \mathrm{L}$ & {$[46]$} \\
\hline Amman Zarqa Basin, Jordan & Middle aquifer & $1.5-742 \mu \mathrm{g} / \mathrm{L}$ & {$[46]$} \\
\hline Ireland & Seleniferous soils & Up to $1200 \mathrm{mg} / \mathrm{kg}$ & {$[47]$} \\
\hline Japan & Industrial wastewater & $\leq 0.1 \mathrm{mg} / \mathrm{L}$ & {$[48]$} \\
\hline Jaipur, India & Groundwater & $341 \mu \mathrm{g} / \mathrm{L}$ & {$[47]$} \\
\hline USA & Seleniferous soils & Up to $28 \mathrm{mg} / \mathrm{kg}$ & {$[47]$} \\
\hline China & Seleniferous soils & $\mathrm{Up}$ to $59 \mathrm{mg} / \mathrm{kg}$ & {$[47]$} \\
\hline Chennai, India & Groundwater & $\mathrm{Se}(\mathrm{VI}) 0.16-4.73 \mu \mathrm{g} / \mathrm{L}$ & {$[49]$} \\
\hline Chennai, India & Groundwater & $\mathrm{Se}(\mathrm{IV}) 0.15-0.43 \mu \mathrm{g} / \mathrm{L}$ & {$[49]$} \\
\hline Hisar, India & Groundwater & $3.2 \mu \mathrm{g} / \mathrm{L}$ & {$[47]$} \\
\hline Chandigarh, India & Groundwater & $0.9 \mu \mathrm{g} / \mathrm{L}$ & {$[47]$} \\
\hline California's San Joaquin Valley, USA & Drainage water of soils & $75-1400 \mu \mathrm{g} / \mathrm{L}$ & {$[50]$} \\
\hline Ethiopian Rift Valley & $\begin{array}{l}\text { Drinking water, deep wells } \\
\text { shallow wells, hot springs, } \\
\text { springs and rivers }\end{array}$ & $0.02-6.8 \mu \mathrm{g} / \mathrm{L}$ & {$[38]$} \\
\hline $\begin{array}{l}\text { Tinishu Akaki River, Lake Awassa, and } \\
\text { Lake Ziway, Ethiopia }\end{array}$ & Water & $<0.94-2.0 \mu \mathrm{g} / \mathrm{L}$ & {$[39]$} \\
\hline Akaki River, Ethiopia & Sediment & $0.09 \mu \mathrm{g} / \mathrm{kg}$ & {$[40]$} \\
\hline Lake Awassa and Lake Ziway, Ethiopia & Sediment & $46.9-120 \mu \mathrm{g} / \mathrm{kg}$ & {$[41]$} \\
\hline Lake Ziway, Ethiopia & Water & $0.83-10.4 \mu \mathrm{g} / \mathrm{L}$ & {$[42]$} \\
\hline Ethiopia & Tap water, bottled water, \\
well water, river water & $0.66-7.0 \mu \mathrm{g} / \mathrm{L}$ & This study \\
\hline
\end{tabular}

\section{CONCLUSION}

This study was carried out to determine the level of selenium in some of the selected water samples of Ethiopia by MP-AES. Eleven water samples were assessed for their selenium content. The concentration of the targeted samples was found in the range of 0.66 to $6.99 \mu \mathrm{g} / \mathrm{L}$, which is in the range of recommendation set by the World Health Organization and the Ethiopian Standards Agency. Akaki Kality River water sample contains the highest level of selenium. From this, it is possible to infer that anthropogenic activates in and around Addis Ababa city are the possible source of selenium. Well water at Ziqualla Wogem contains the least amount of selenium. Thus in the area, the parent rocks seems to contain less amount of selenium. From this study, it can be concluded that the variations in Se level of the samples at different sites of well water is due to the variations of natural source of selenium. Except for bottled water samples, the ANOVA results at a $95 \%$ confidence level suggest that there is a significant difference in the mean concentration of selenium in all samples. These differences could be attributed to the different natural and anthropogenic sources of selenium. 


\section{ACKNOWLEDGMENTS}

The authors are thankful to the Department of Chemistry, Addis Ababa University, Addis Ababa, Ethiopia for providing laboratory facilities. Ayenew Minuye would like to acknowledge the Chemical and Construction Input Industry Development Institute, Ethiopia for sponsoring his study.

\section{REFERENCES}

1. Adriano, D.C. Trace Elements in the Terrestrial Environment: Biogeochemistry, Bioavailability and Risks of Metals, 2nd ed., Springer-Verlag: New York; 2001; $\mathrm{p} 871$.

2. Natasha, M.; Shahid Niazi, N.K.; Khalid, S.; Murtaza, B.; Bibi, I.; Rashid, M.I. A critical review of selenium biogeochemical behavior in soil-plant system with an inference to human health. Environ. Pollut. 2018, 234, 915-934

3. Gebreeyessus, G.D.; Zewge, F. A review on environmental selenium issues. SN Appl. Sci. 2019, 1, Article no. 55. DOI: 10.1007/s42452-018-0032-9.

4. Duntas, L.H.; Benvenga, S. Selenium: An element of life. Endocrine 2015, 48, 756-775.

5. Combs, G.F.; Gray, W.P. Chemopreventive agents: Selenium. Pharmacol. Therap. 1998, 79, 179-192.

6. Rayman, M.P. The importance of selenium to human health. Lancet 2000, 356, 233-241.

7. Goldhaber, S.B. Trace element risk assessment: Essentiality vs toxicity. Regulat. Toxicol. Pharmacol. 2003, 38, 232-242.

8. Taylor, J.B.; Reynolds, L.P.; Redmer, D.A.; Caton, J.S. Maternal and fetal tissue selenium loads in nulliparous ewes fed supra nutritional and excessive selenium during mid- to late pregnancy. J. Animal Sci. 2009, 87, 1828-1834.

9. Burger, J.; Gochfeld, M. Selenium and mercury molar ratios in saltwater fish from New Jersey: Individual and species variability complicate use in human health fish consumption advisories. Environ. Res. 2012, 114, 12-23.

10. Penglase, S.; Hamre, K.; Ellingsen, S. Selenium and mercury have a synergistic negative effect on fish reproduction. Aquat. Toxicol. 2014, 149, 16-24.

11. Kaur, G.; Ponomarenko, O.; Zhou, J.; Swanlund, D.P.; Summers, K.L. Dolgova, N.; Antipova, O.; Pickering, I.; George, G.N.; Leslie, E.M. Studies of selenium and arsenic mutual protection in human HepG2 cells. Chemico-Biological Interactions 2020, 327, Article no. 109162. DOI: 10.1016/j.cbi.2020.109162.

12. Liu, C.; Zhang, L.; Wu, Q.; Qu, G.; Yin, Y.; Hu, L.; Shi, J.; Ziang, G. Mutual detoxification of mercury and selenium in unicellular Tetrahymena. J. Environ. Sci. 2017, DOI: 10.1016/j.jes.2018.02.004.

13. Young, T.G.; Finley, K.; Adams, W.J.; Besser, J.; Hopkins, W.D.; Jolley, D., McNaughton, E.; Presser, T.S.; Shaw, P.; Unrine, J. Ecological Assessment of Selenium in the Aquatic Environment, CRC Press: Boca Raton; 2010; pp. 7-46.

14. Fairweather-Tait, S.J.; Bao, Y; Broadley, M.R. Selenium in human health and disease. Antioxid. Redox Sign. 2011, 14, 1337-1383.

15. Santos, S.; Ungureanu, G.; Boaventura, R.; Botelho, C. Selenium contaminated waters: An overview of analytical methods, treatment options and recent advances in sorption methods. Sci. Total Environ. 2015, 521, 246-260.

16. Lemly, A.D. A procedure for setting environmentally safe total maximum daily loads for selenium. Ecotoxicol. Environ. Safe. 2002, 52, 123-127.

17. US EPA. External Peer Review Draft Aquatic Life Ambient Water Quality Criterion for Selenium Freshwater 2014, EPA-820-F-14-005, United States Environmental Protection Agency: Washington, DC.; 2014.

18. World Health Organization. Guidelines for Drinking-Water Quality. 4th ed., World Health Organization: Geneva; 2011. 
19. European Commission. Council Directive 98/83/EC of 3 November 1998 on the quality of water intended for human consumption. Official J. Eur. Commun. 1998, 330, $32-54$.

20. Agriculture and Resource Management Council of Australia and New Zealand and the Australian and New Zealand Environment and Conservation Council. Australian and New Zealand Guidelines for Fresh and Marine Water Quality: Volume 1 - The Guidelines, Department of the Environment: Australian Government; 2000.

21. Department of Water Affairs and Forestry. South African Water Quality Guidelines, Second Edition, South Africa; 1996.

22. Union of India. General Standards for Discharge of Environmental Pollutants, Himachal Pradesh State Pollution Control Board, India; 1993.

23. Canadian Council of Ministers of the Environment. Summary Table - Selenium, Canadian Environmental Quality Guidelines, Canada; 2009.

24. British Columbia Ministry of Environment. Ambient Water Quality Guidelines for Selenium Technical Report Update, Canada; 2014.

25. Ethiopian Standards Agency. Drinking Water-Specification. CES 58, Compulsory Ethiopian Standard, First Edition, ICS: 13.060.20. Ethiopian Standards Agency: Addis Ababa, Ethiopia; 2013.

26. Winkel, L.H.E.; Vriens, B.; Jones, G.D.; Schneider, L.S.; Pilon-Smits, E.; Bañuelos, G.S. Selenium cycling across soil-plant-atmosphere interfaces: A critical review. Nutrients 2015, 7, 4199-4239.

27. Mitchell, K.; Mason, P.R.D.; Van Cappellen, P.; Johnson, T.M.; Gill, B.C.; Owens, J.D.; Diaz, J.; Ingall, E.D.; Reichart, G.-J.; Lyons, T.W. Selenium as paleo-oceanographic proxy: A first assessment. Geochim. Cosmochim. Acta 2012, 89, 302-317.

28. Vance, F.W.; Smith, K.; Lau, A.O. Evaluation of treatment techniques for selenium removal, 70th Annual International Water Conference, Engineers Society of Western Pennsylvania (ESWP), Curran Associates, Inc.: Orlando, Florida, USA; 2009; pp 35-52.

29. Wasewar, K.L.; Prasad, B.; Gulipalli, S. Adsorption of selenium using bagasse fly ash. Clean Soil Air Water 2009, 37, 534-543.

30. DeForest, D.K.; Brix, K.V.; Adams, W.J. Critical review of proposed residue based selenium toxicity thresholds for freshwater fish. Human Ecol. Risk Assess.1999, 5, 1187 1228.

31. Hamilton, S.J. Rational for a tissue-based selenium criterion for aquatic life. Aquat. Toxicol. 2002, 57, 85-100.

32. Chapman, P.M. Selenium thresholds for fish from cold freshwaters. Human Ecol. Risk Assess. 2007, 13, 20-24.

33. US EPA. Aquatic Life Ambient Water Quality Criterion for Selenium Freshwater 2016. EPA 822-R-16-006, U.S. Environmental Protection Agency, Office of Water: Washington, DC (USA); 2016.

34. Thiry, C.; Ruttens, A.; De Temmerman, L.; Schneider, Y.J.; Pussemier, L. Current knowledge in species-related bioavailability of selenium in food. Food Chem. 2012, 130, 767-784.

35. Lavado, R.; Shi, D.; Schlenk, D. Effects of salinity on the toxicity and biotransformation of L-selenomethionine in Japanese medaka (Oryzias latipes) embryos: Mechanisms of oxidative stress. Aquat. Toxicol. 2012, 108, 18-22.

36. Spallholz, J.E.; Hoffman, D.J. Selenium toxicity: Cause and effects in aquatic birds. Aquat. Toxicol. 2002, 57, 27-37.

37. Mézes, M.; Balogh, K. Prooxidant mechanisms of selenium toxicity a review. Acta Biologica Szegediensis 2009, 53, 15-18.

38. Reimann, C.; Bjorvatn, K.; Frengstad, B.; Melaku, Z.; Tekle-Haimanot, R.; Siewers, U. Drinking water quality in the Ethiopian section of the East African Rift Valley I-data and health aspects. Sci. Total Environ. 2003, 311, 65-80. 
39. Mekonnen, K.N.; Ambushe, A.A.; Chandravanshi, B.S.; Redi-Abshiro, M.; Mccrindle, R.I. Potentially toxic elements in some fresh water bodies in Ethiopia. Toxicol. Environ. Chem. 2012, 94, 1980-1994.

40. Mekonnen, K.N.; Ambushe, A.A.; Chandravanshi, B.S.; Redi-Abshiro, M.; Mccrindle, R.I. Assessment of potentially toxic elements in Swiss chard and sediment of Akaki River, Ethiopia. Toxicol. Environ. Chem. 2014, 96, 1501-1515.

41. Mekonnen, K.N.; Ambushe, A.A.; Chandravanshi, B.S.; Redi-Abshiro, M.; Mccrindle, R.I. Occurrence, distribution and ecological risk assessment of potentially toxic elements in surface sediments of Lake Awassa and Lake Ziway, Ethiopia. J. Environ. Sci. Health, Part A 2015, 50, 90-99.

42. Merga, L.B.; Mengistie, A.A.; Faber, J.H.; Van den Brink, P.J. Trends in chemical pollution and ecological status of Lake Ziway, Ethiopia: a review focussing on nutrients, metals and pesticides. Afr. J. Aquatic Sci. 2020, 1-15. DOI: 10.2989/16085914.2020.1735987.

43. US EPA. Acid digestion of aqueous samples and extracts for total metals, Method 3010A, 1992. U.S. Environmental Protection Agency, Office of Water: Washington, DC (USA); 1992; p 1-5.

44. Yilkal, E.; Zewge, F.; Chandravanshi, B.S. Assessment of the quality of bottled water marketed in Addis Ababa, Ethiopia. Bull. Chem. Soc. Ethiop. 2019, 33, 21-41.

45. Luoma, S.N. Emerging opportunities in management of selenium contamination. Environ. Sci. Technol. 2009, 43, 8483-8487.

46. Al Kuisi, M.; Abdel-Fattah, A. Groundwater vulnerability to selenium in semi-arid environments: Amman Zarqa Basin, Jordan. Environ. Geochem. Health 2010, 32, 107-128.

47. Bajaj, M.; Eiche, E.; Neumann, T.; Winter, J.; Gallert, C. Hazardous concentrations of selenium in soil and groundwater in North-West India. J. Hazard. Mater. 2011, 189, 640646.

48. Soda, S.; Kashiwa, M.; Kagami, T.; Kuroda, M.; Yamashita, M.; Ike, M. Laboratory scale bioreactors for soluble selenium removal from selenium refinery wastewater using anaerobic sludge. Desalination 2011, 279, 433-438.

49. Ramesh Kumar, A.; Riyazuddin, P. Speciation of selenium in groundwater: Seasonal variations and redox transformations. J. Hazard. Mater. 2011, 192, 263-269.

50. Zelmanov, G.; Semiat, R. Selenium removal from water and its recovery using iron $\left(\mathrm{Fe}^{3+}\right)$ oxide/hydroxide-based nanoparticles sol (nano Fe) as an adsorbent. Sep. Purif. Technol. 2013, 103, 167-172. 